\title{
The Applied Research of Contestable Market Theory in the Development of the Theory of Industrial Organization
}

\author{
Shan Chen \\ School of Economics and Management \\ Beijing Jiaotong University \\ Beijing , China \\ mm19530208@hotmail.com
}

\begin{abstract}
With the theory of industrial organization continuing to mature, theory of contestable markets which was created in 1975, by analyzing perfectly contestable markets and the sunk cost, illustrated the question of the relationship between the size of the enterprise and the degree of competition. It makes industrial organization theory develop to some extent, and provides a new thinking way for the system reform.
\end{abstract}

Keywords- the theory of industrial organization; theory of contestable markets; fully contestable marke; sunk costs.

\section{INTRODUCTION}

Industrial organization theory is an important part of modern economics, it is one of emerging applied economic theory used to analyze and study the economic operation under the conditions of market economy. Industrial organization theory is based on price theory. Through analyzing the relationship and contradiction of competition, monopoly and economies of scale among the Intra-industry enterprises in the development of modern market economy, it researches and explores their impact on efficiency of resource allocation within the industry, in order to provide a theoretical basis and measures for maintaining a reasonable market order and economically efficient. Up to 1980 s, along with the advent of the theory of Contestable Market, which was proposed by W.J.Baumol, J.C.Panzar and R.D.Willing, industrial organization theory has been developed.

\section{DEFINITION OF INDUSTRIAL ORGANIZATION THEORY AND ITS DEVELOPMENT}

\section{A. Definition of Industrial Organization Theory}

Industrial organization theory can be broadly defined as a kind of economic theory connected with the market, which is not easy to be analyzed with the model of compete in the standard textbook. Industrial organization theory appeared in 1930s and has been developed in Western countries since then, it is a microscopic applied Economics. Its main object of study is market structure, market behavior, market performance and their internal relations in special industry to reveal the inherent regularity of the activities of industrial organization. Its aim is to provide decision-making basis for real economic activity participants and to provide policy recommendations for policymakers.

\section{B. Development of Industrial Organization Theory}

The development of the economic theories is always linked to specific historical period. In the 15th and 16th centuries, Western Europe was in the late feudal society, this period was the era of pirate colonialism, in which the rise of mercantilism reflected the interests and requirements of the commercial and it played active role in rapid development of industry and commerce of Western Europe capitalism. From 17th century to the early 19th century, capitalism got rid of constraints from feudalism, at that time the theory of the division of labor and competition theory of Adam - Smith, who was the representative of classical economists, played a positive role in promoting the early development of capitalism.

To the late 19th and early 20th century, the capitalism transited from free competition to monopoly capital period. During this period the monopoly has become a common phenomenon. In 1890, United States passed its first AntiMonopoly law - the Sherman Act, the practice of antiMonopoly provoked scholars' debate about the pros and cons of monopolies.

During late 19th century, neo-classical economics which representative is Marshall firstly gave a comprehensive exposition to so-called perfectly competitive market, noting that the monopoly will bring monopoly profits or the rising of equilibrium prices, which will impede optimal allocation of resources. However, they still considered that monopoly is just a temporary phenomenon in competition process; long-term main force to regulate the market equilibrium is still the invisible hand of the market mechanism. Until 1933, Chamberlain and Robinson respectively published "Imperfect competition economics" and "Theory of monopolistic competition", which studied monopolistic competition issues more deeply. In the theory of monopolistic competition, they put forward: Because of differentiation of product, in the real typical market structure there really is the monopolistic competition, not perfectly competitive. In market structure of monopolistic competition, firms have "market force" to determine the certain price, which can guarantee that long-term monopolistic profits is more than zero. Therefore, the 
spontaneous role of market mechanisms alone is not enough to achieve the optimal allocation of resources, in this case the government must intervene the monopolistic power in order to ensure proper market competition.

In 1938, Mason established industrial organization research group at Harvard University and proposed analysis system of the theory of industrial organization and its research directions. J.S. Bain in 1956 began to study the barriers of entry to the market, and in 1959 published "industrial organization ", in which he summarizes the existing research results and at first noted comprehensively and systematically theoretical system of the industrial organization, which marked the forming of the theory of industrial organization as a branch of economics; at the same year, economists Kaisen and jurists Turner copublished " Antitrust Policy" [1]. The theory of monopolistic competition sparked to think deeply about a series of practical problems. In studying and resolving these issues, theory of industrial organization was created and developed. The traditional industrial organization theory and new industrial organization theory

The earliest theory of industrial organization was found in the related study by Harvard Mason professor and his disciples Bain (J. Bain). In 1959,in his first textbook about the theory of industrial organization "Industrial Organization ", Bain clearly explained the purpose and measure of research of industrial organization, implying that the Harvard School was officially formed. Harvard School used evidence- sectional analysis methods to derive that there is a one-way causal link between market structure, market behavior and market performance: concentration determines the level of the company's market behavior, in turn the latter determines the quality of performance of enterprise market. This is the analysis paradigm of the theory of industrial organization, namely "structureconduct-performance " (in short SCP) .

The original form of this paradigm is two phase paradigm of Bain (1956). The popular SCP syllogism paradigm in Modern mainstream industrial organization theory was what Scherer evolved on the basis of two phase paradigms of Bain. According to this analysis paradigm, highly concentrated enterprises of industry tend to raise prices and set obstacles in order to reap monopolistic profits, and impede technological progress resulting in inefficient resource configuration. To get a good market performance, the most important thing is to adjust and improve the irrational market structure through public policies, limiting the development of monopolistic power to maintain market moderate competition[2-4]. The forming of SCP paradigm marks the initial maturity of the system of industrial organization theory.

However, in the subsequent development, the connotation of SCP analysis paradigm has changed greatly. In 1960s to 1970s, the U.S. economy in the international competition forces tended to decline, there was "stagflation" phenomenon in its economy, many researchers and analysts mainly attributed it to tough anti-monopoly policy proposed by Harvard School. From the late 1970s, Stigler (J. Stigler), representing the University of Chicago, attacked the views of Harvard School scholars and formed " Chicago School "in the theory of industrial organization. They proposed that the problem of industrial organization should be illustrated with the theory of perfect competition rather than the theory of monopolistic competition. Accordance with the theory of the scale of economy, the size of the enterprise' scale economy will expand with rising of technological level; meanwhile the average cost will be constantly reduced. Therefore, as long as the expansion of business scale is consistent with the rising of technological level, that is necessary and reasonable. Thus they concluded that expansion of business scale not only does not cause waste of resources, but it will improve resource utilization efficiency because of the decrease of the average cost [5]. For the problem of relationship between enterprise scale and the degree of competition, they described it according to "contestable market theory".

Contestable market theory thinks that as long as market entry is completely free, there will not be any special cost into and out of the market; the potential competitive pressures will force every company in market structure to adopt competitive behavior, even if a company fully monopolizes the market [6]. Meanwhile, as long as potential competitors enter and exit the market at that time fully accessibly, manufacturers available on the market - whether it is just a business or has many active vendors, always faced competition from potential entrants pressure .Thus in order to avoid attracting more competitors, pricing and yield selection of the original enterprise will always be forced to be in a " equilibrium constraints of no significant excess profits " ( Baumol, 1988).This is not like what the Harvard School said, namely that large firms can arbitrarily set prices and access high monopolistic profits. "Contestable market theory "describes that expansion of business scale or increasing of concentration does not mean the increasing of degree of monopoly and the declining of the degree of competition. On the basis of above two aspects of analysis, Chicago School proposed that when people judge whether a company is monopoly or not, they cannot judge it according to the level of concentration and the size of a business, and should still not implement tougher anti-monopoly policy without distinction to large enterprises. It states that the criterion should be what corporate performance is good or bad, and unnecessary controls of the large enterprises should be relaxed. Traditional research has been concerned about which policy measures were taken to prevent competitors from entering the market. After contestable market theory was proposed, more research has turned to the potential competition and market structure with accessible features, which to some extent improved the theory of industrial organization.

\section{CONTESTABLE MARKET THEORY}

In 1982, in the "Contestable Market and Industry structure theory ", Baumol, Panzar and Wiling systematically proposed the theory of contestable markets, marking the formation of the theory of contestable markets. The contestable market refers to those markets in which there is the pressure from potential entrants and a strong constraint to existing manufacturer's behavior. Contestable market theory is around the concepts such as fully contestable market and sunk costs; it derives the basic trend of an efficient, sustainable industrial organization and its endogenous formation process. Contestable market 
theory is an important achievement of development of the theory of industrial organization.

\section{A. Fully Contestable Markets}

Fully contestable market is a kind of competitive market structure with "super- free", in it there is not a variety of entrance barriers of Stigler or Bain; companies can exit an industry without cost. According to contestable market standards in the industrial organization theory, as long as the market is fully contestable, namely that the market is free to enter and exit without cost, it can effectively constrain market monopolist even if it is just invasion threat from market entrants; even if invasion do not succeed, it will force the monopolist to constrain its greed, and abandon all likely high profits to enjoy [7]. In a fully contestable market, "full access" is beneficial to obtain Pareto optimal market behavior, and to a certain extent eliminate the complexity of strategic behavior, making the behavior of the competition to be uniquely determined by the strength of potential competition. Namely, when enterprises within the market want to exits from the market, they can be completely without the burden of nonrecoverable sunk costs, so they can completely free to enter and exit the market. As businessmen enter and exit the market completely freely, those who want to enter did not have disadvantage in production technology or yield. An important symbol of a fully contestable market is the lack of prevention force to quick access. In short, fully contestable conditions are that there is not any cost discrimination to entrants. Fully contestable market is the reference what contestable theory analyzes industry structure and behavior performance characteristics.

\section{B. Sunk Costs}

From the definition of the fully contestable market, whether market is contestable or not, it just depends on whether there are sunk costs or not, it has nothing to do with the number of firms within the industry. The so-called "sunk cost" refers to that part of the investment which enterprises cannot recover when they enters and exits the market. For example, even though the production equipment and plant buildings held by business that want to exit, can be granted or used for other purposes, but due to the lower granting price or the less of value in use, business cannot recover investment costs cannot be recovered part, or difficult to recover and thus can only deal with undepreciated portion of tangible assets in invalidated way, as well as for other intangible asset expenditures such as research and development, advertising, employee training and so on( due to special nature of this part of the expenses, they cannot be used for other uses and are difficult to recycle ). Thus, Baumol and others were concerned specially about sunk cost, the sunk degree of which mainly depends on the possibility of invested capital transferred to other markets or recovery of capital grant and it has nothing to do with fixed invested costs.

Whatever fixed fee or part of the asset is more or less, as long as it can be recovered, it is not sunk cost. Sunk costs determine the degree of difficulty and easiness of the enterprise withdrawal from the market, thus affecting the decision of the enterprise's entrance. Once entering, the more the cost of enterprise withdrawal is, the more cautious decision-making of enterprises entrance is. Therefore, the greater the sunk costs are, the smaller the pressures of market entrance are, and thus the smaller the pressures of existing firms are. At this point, contestable market theory of Baumol et al is different from the traditional industrial organization theory, which thinks that economies of scale, product differentiation and absolute cost differences are determinants of barriers to entry.

\section{THE ROLE OF CONTESTABLE MARKETS THEORY IN NEW INDUSTRIAL ORGANIZATION THEORY}

Since appearance of the pioneering research from Bain (Bain, 1949), the barriers to entry and prevented entering have been the focus of the theory of industrial organization. In so far as the new theory of industrial organization, this field of research focused on two aspects: What behavior can successfully stop entering and what are the welfare effects of the barriers to entry? Moreover, Jovanovic (Jovanovic, 1982) published his seminal paper, since then dynamics research about a particular industry entry and exit in a given period has also become a new focus of new industrial organization theory in1990s. Contestable markets theory has researched issues of barriers to entry in industrial organization theory.

In the new economic conditions, due to improvements of technological level and the organizational form, barriers to entry fall, the sunk costs decline and new contestable markets are formed, which make the market's "potential competition" strengthened. In the fully contestable market, because sunk cost is zero, potential entrants for the pursuit of profit will quickly go to any sectors with high profits, and be able to withdraw rapidly without friction before existing firms react to entering, and do not expend special costs. This form of entry is often called as the "hit and run" strategy (Hit-and-Run Entry).

If the pricing behavior of existing firms provides a profitable opportunity, potential entrants will quickly enter and can exit in unscathed way before existing firms to make reaction to price. To make those who want to enter no longer have the profitable opportunities, fully contestable industrial equilibrium must have no excess profits, efficiency pricing and other features. Whether there are only one or many competing manufacturers on the market, fully contestable market always has these characteristics. The reason is that an effective constraint to equilibrium behavior of existing enterprises on the market is potential competition from potential entrants, rather than the competition among existing firms. The retention duration of the enterprises with this aggressive behavior to enter the market in this industry, usually depends on the response time of existing enterprises. However, even if it is a brief profit opportunities, it will also attract potential entrants to enter, and they make any firm foothold before the existing business reflects to structure [8]. Finally, withdrawal from the market is completely free and need not pay a price, therefore, when existing enterprises make reprisals reflection to force the price to drop to unprofitable state, they will leave the market with the profits. Visibly, the nature of the contestable market is that this market cannot refuse those "hit and run" entrants. And similar with the thought of the Chicago school, contestable market theory is still based on equilibrium analysis of neoclassical economics and emphasizes long-term analysis. The equilibrium in the long term to achieve is one in which 
both the process of market entry and exit are in a static state, namely, on the one hand enterprises on the existing market do not have motivation of withdrawal from the market because they have no loss; on the other hand, the enterprise in the potentially competitive position have not high profit. Here, it is potential entrants' potential competition, rather than the existing competition among enterprises, to pull the equilibrium of fully contestable toward the welfare optimization.

In accordance with the theory of contestable markets, in approximately fully contestable market, laissez-faire policy is more effective than the usual anti-monopolistic policy and government regulation policy. A few large enterprises make vertical merger or horizontal mergers, the traditional view thinks that they will bring drawbacks of the monopoly, but in the contestable market conditions, they have become harmless and may even be more efficient. Of course, contestable market theory does not consider all substantial government regulation and anti-monopolistic measures should not be taken and are harmful interference. In Baumol et al, the government's competition policy should rather pay attention to the market structure than whether there are sufficient potential competitive pressures, to ensure that the key of existing of potential competitive pressures is to minimize sunk costs [9].

However, in reality, the assumptions that truly meet the contestable market theory have also been strongly criticized by many economists. For example, some studies show that in most markets such cost is more obvious in short-term than in longterm, small firms are more flexible than large firms. New entrants have corresponding proportion of the potential pricing advantage, and so on. But in practice, the existing enterprises have greater advantage in the production technology, perceived product quality and marketing network and so on. If the existing businesses and new entrants can also obtain financing, the major manufacturers engaged in diversification may enter the market, and large manufacturers cannot take "hit and run" strategy in the market. This indicates that the scope of the theory has still significant limitations in practical terms. Nevertheless, the theory of contestable markets play important role in the past two decades, such as thinking conversion of regulation policy and production adjustment of U.S. and Britain and other developed market economic states.

\section{SigNifiCANCE AND IMPACT OF CONTESTABLE MARKET THEORY}

Contestable market theory has certain theoretical and policy significance, especially for deregulation. According to contestable theory, if the market is contestable or can make market contestable, the potential competitive threat will need government intervention in the market, the reason is that it can eliminate any generic market power. Elimination of barriers to entry and opening markets can contribute to the formation of a contestable market. Meanwhile they can make the focus of the government market policy changed, from market behavior of intervention and regulation towards relaxing the competitive market environment. Generation of contestable market theory has a direct relationship with intrinsic defects of traditional microeconomic theory and problems in the application of it. This theory had a significant impact on Western national control policies and regulatory practices, while it presents a set of concepts and methods to analyze multi-product industry.

\section{CONCLUSIONS}

SCP paradigm proposed by industrial organization theory is recognized as an important innovation of industrial organization theory. It has become the core of the industrial organization theory and an important tool. But there are some questions in metrics of industrial organization theory, for example, contestable standard often cannot be measured with whether entry or exit is free or not and there is cost or not. Due to competitive entry restrictions, the market is non- contestable, so that the specific relationship among the SCP paradigms will present different characteristics. In the market where there are significant economies of scale and scope economies, fully contestable standards may not be applicable. Contestable market theory analyzed problems of the barriers to entry in industrial organization theory and redefined the enterprise scale and scope economies. Through them, we found its scope of application and the market will be more open although the contestable market theory has its application terms. The introduction of contestable market can make industrial organization theory to a certain extent developed and provides a thinking way for system reform.

\section{ACKNOWLEDGMENT}

This work has been supported by Soft Science Research Project in Hubei Province ( No.2012GDA00401 ).

\section{REFERENCES}

[1] Christopher $\mathrm{R}$ Thomas. Managerial Economics [M]. Beijing : Mechanical Industry Press, 2010

[2] Wong Chun . 's Comments on the contestable market [J]. Business Economics and Management, 2001 ( 4 ) :19- 21.

[3] YANG Yan New Economy theory of contestable markets and government regulation Innovation [D]. Hunan : Hunan Normal University, 2006.

[4] Huang Weiwei . Asymmetric Competition [M]. Beijing : Enterprise Management Publishing House, 2008.

[5] Donald - sea - Derek Morris . Industrial Economics and Organization [M]. Beijing : Economic Science Press , 1998.

[6] Yan Xingyu . Summary contestable market theory [J]. Industrial Economics Research ,2009,1:69 -76.

[7] Wong Chun . Contestable market theory on the review [J]. Business Economics and Management ,2001,4:19-21 .

[8] Ding heavy . Evolution of Industrial Organization Theory and Postmodern Analysis [J]. Industry and Technology Forum , 2012,11 ( 15 ) :25- 27

[9] Wang Guoping . Our modern industrial system optimization flags , conditions and Route [J]. National School of Administration , 2012 ( 3 ) : $: 21-25$ 